\title{
Dynamics of Urban Growth in Semarang Metropolitan - Central Java: An Examination Based on Built-Up Area and Population Change
}

\author{
Wiwandari Handayani ${ }^{1}$ \& Iwan Rudiarto ${ }^{1}$ \\ ${ }^{1}$ Department of Urban and Regional Planning, Diponegoro University, Indonesia \\ Correspondence: Wiwandari Handayani, Department of Urban and Regional Planning, Diponegoro University, \\ Semarang, Central Java, 50275, Indonesia. Tel: 24-7648-0856. E-mail: wiwandari.handayani@undip.ac.id
}

Received: August 20, 2014 Accepted: September 23, 2014 Online Published: November 9, 2014

doi:10.5539/jgg.v6n4p80

URL: http://dx.doi.org/10.5539/jgg.v6n4p80

The research is financed by the Engineering Faculty of Diponegoro University.

\begin{abstract}
Representation of rapid urban growth followed by high rate of land conversion is clearly observed in the case of Semarang Metropolitan. Located in Java Island, this capital city has been performing as the largest urban area in the Central Java Province. This paper aims to examine urban growth pattern in Semarang Metropolitan by applying two main indicators, i.e., (1) additional built-up area 1972-2009 indicated as land conversion, and (2) population change between 1991-2008. Accordingly, distance is regard as an important parameter to further examine the emerging pattern based on the two indicators. Remote Sensing (RS) and Geographical Information System (GIS) were used to analyze satellite images and built-up area development from the different periods. The analyses result show that suburbanization has been taken place in Semarang Metropolitan. The emerging pattern is very common in Asian cities as it is very much similar with the pattern in view selected cities in the neighboring countries (Jakarta, Bangkok, Metro Manila).
\end{abstract}

Keywords: urbanization, urban growth, suburbanization, Semarang

\section{Introduction}

Rapid urbanization is a common phenomenon found in many urban areas in different countries. According to the United Nations (2004), world urban population is 30 percent in 1950. It has increased to 50.5 percent in 2010 . In Asia, urban population has been steadily increased from 17.4 percent in 1950 to 37.5 percent in 2000 . The number is expected to increase further to 54.1 percent in 2030. Eventhough, mainly in Asia, urban growth occurs at a different speed for different places and a lot of confusion is present to measure the growth accurately (Cohen, 2006; Jones, 2004), there is still common acceptable fact that urban expansion in Asia take place within a short span of time in comparison to what has happened in the western urbanization.

In Indonesia, intensive urban growth highly concentrated only in Java Island while actually the Island also contributes a significant area of arable land mostly for paddy field to produce rice, staple food in the country (Tambunan, 2003). According to CBS data (2001), the people who are defined as living in urbanized area in Java Island has risen from 25.1 percent in 1980 to 48.7 percent in 2000 . It is also important to note that almost 70 percent of Indonesian urban population live in Java while Java contributes only 6.75 percent of total Indonesian area (CBS in Firman, 2004).

Representation of rapid urban growth followed by high rate of land conversion is clearly observed in the case of Semarang Metropolitan. Located in Java Island, this capital city has been performing as the largest urban area in the Central Java Province. Number of population in Semarang Metropolitan in 1970s was around 700,000 inhabitants (Pratiwo, 2004). It has been growth to around 1,500,000 inhabitants in 2010 and with status quo scenario, projected to 2,100,000 inhabitants in 2030 (CBS, 2010). The additional urban population leads to a need for an urban expansion to accommodate growing population and mostly to accommodate required land demand for such urban activities. Indeed, the urban growth phenomenon in Semarang Metropolitan does a matter. Accordingly, an important issue emerge that is a debate over metropolitan compactness versus 'sprawl'.

There are a lot of debates in representing urban growth pattern, not only in terms of distinguishing the degree of compactness and sprawl but also in terms of how the developed pattern will be able to promote sustainable 
development (Torrens, 2008; Jabareen, 2006; Breheny, 2005). Stricter urban containment which may lead to compactness is believed as more environmentally friendly. The compaction is commonly characterized as mixed land use and therefore may produce a shorter journeys along with efficient used of fuels. On the contrary, a more decentralized urban form is considered as more promising to have high quality of life as living in a compact high density environment will have implication to people behaviour (Breheny, 2005).

Along with the discourse concerning on form of urban growth pattern, Torrens (2008), Tsai (2005), and Galster et al (2001) believe that the measurement of compactness or sprawl is likely to lead on a sparkling debate eventhough there are common quantitative variables may be applied to further examine the phenomena. According to Ewing (1997 in Tsai, 2005), degree of compactness and sprawl can be indicated from low density, scattered development, commercial strip development, and leapfrog development phenomena. Galster et al (2001) further proposes seven different dimension of sprawl including continuity, concentration, compactness, centrality, (mono-) nuclearity, mixed uses, and proximity. Torrens (2008) has even further analyse sprawl characterization based on urban studies literature. Indeed, urban growth examination to quantifying sprawl is multifaceted.

In an attempt to figure out the characterization of compaction and/or sprawling form in the research area, this paper aims to examine urban growth pattern in Semarang Metropolitan by applying two main indicators, i.e., (1) additional built-up area 1972-2009 indicated as land conversion, and (2) population change between 1991-2008. Accordingly, distance is regard as an important parameter to further examine the emerging pattern based on the two indicators. Eventhough there are questions on views of ideal future of urban form and also challenges as population growth is differ among regions, density was applied as an indicator to comprehend potential compaction and/or sprawling form for future Semarang Metropolitan.

This paper is organized into four parts. The first part is an introduction to explain the rationale of this study. The second part briefly discussed the study area, data needs and calculation to analyze the additional built-up and population change. The third part presents the results and discusses the emerging urban growth pattern in Semarang Metropolitan. This paper is concluded with some remarks in regard to how the growth patterns have been performing and further have contributed to the urbanization in the study area.

\section{Method}

\subsection{Research Area}

Research area was determined by the assessment of built-up area development in 2009 from satellite image. As the result, it was found that Semarang Metropolitan has widely developed to another administrative area, such as; Demak District, Semarang District, and Kendal District. In total, research area that has been identified from the assessment of built-up area in 2009 is shown in Table 1. Accordingly, Figure 1 illustrates the research area.

Table 1. Distribution of Semarang Metropolitan

\begin{tabular}{lll}
\hline District/City & $\begin{array}{l}\text { Total } \\
\text { Sub district }\end{array}$ & Urban village/village \\
\hline Semarang City & 16 & 193 \\
Semarang District & 2 & 22 \\
Kendal District & 2 & 28 \\
Demak District & 3 & 51 \\
& 23 & 294 \\
\hline
\end{tabular}

Data need for the analyses were derived from the built-up area development and the population change for specific period. The development of built-up area was assessed through the comparison of satellite images from 1972, 1982, 1991, 2001 and 2009 while the population change was identified through the population development from 1991, 2001, and 2008. 


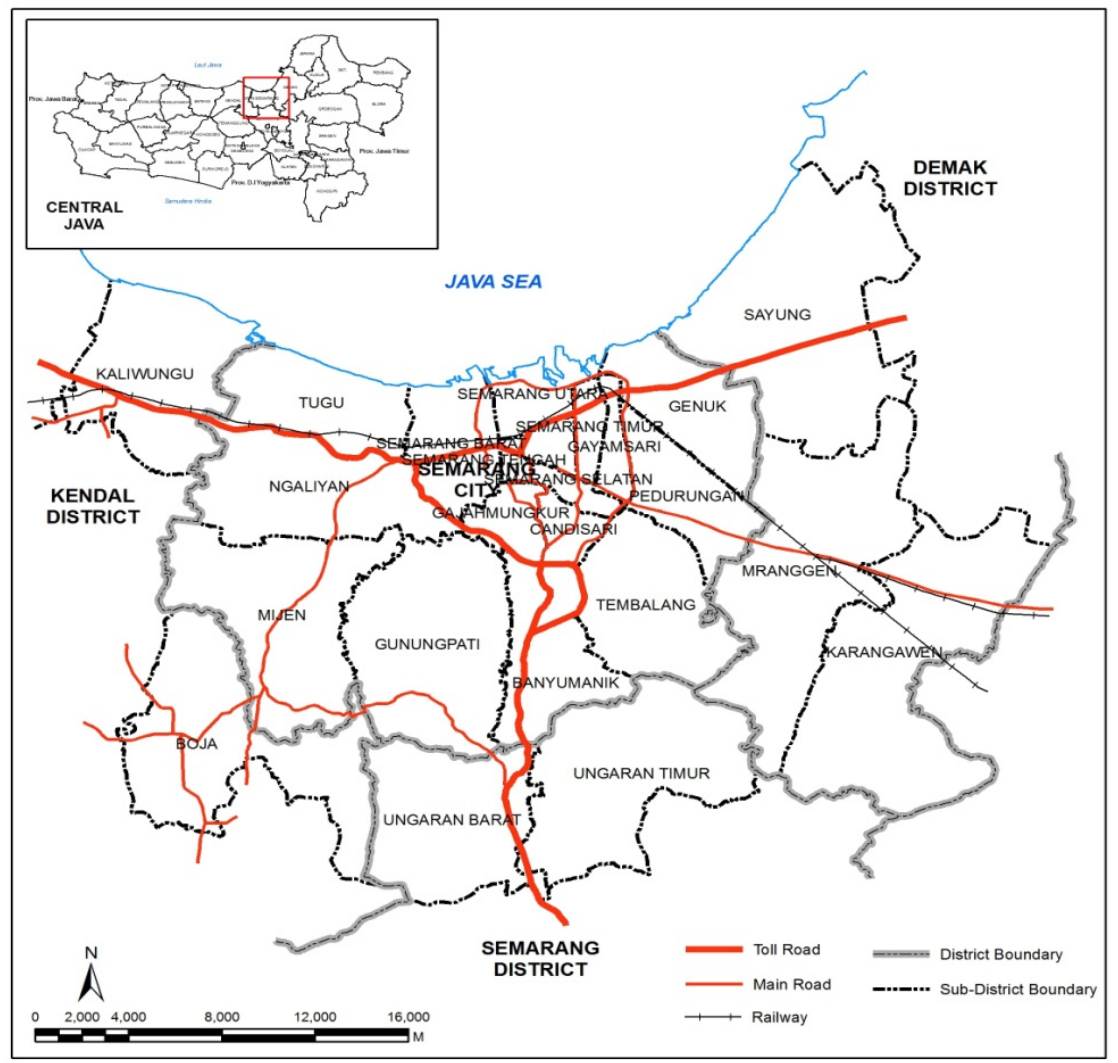

Figure 1. Research area

\subsection{Materials and Methods}

Remote Sensing (RS) and Geographical Information System (GIS) were used to analyze satellite images and built-up area development from different periods. Image analysis was specifically applied to identify built-up area in 1972, 1982, 1991, 2001, and 2009 by using ErMapper software. This analysis used Landsat image as the primary source and supervised classification technique to identify built-up and non built-up area for each respective period. Landsat images used in the analysis were Landsat image 1 for 1972, Landsat image 3 for 1982, Landsat image 5 for 1991, and Landsat 7 TM for 2001 and 2009.

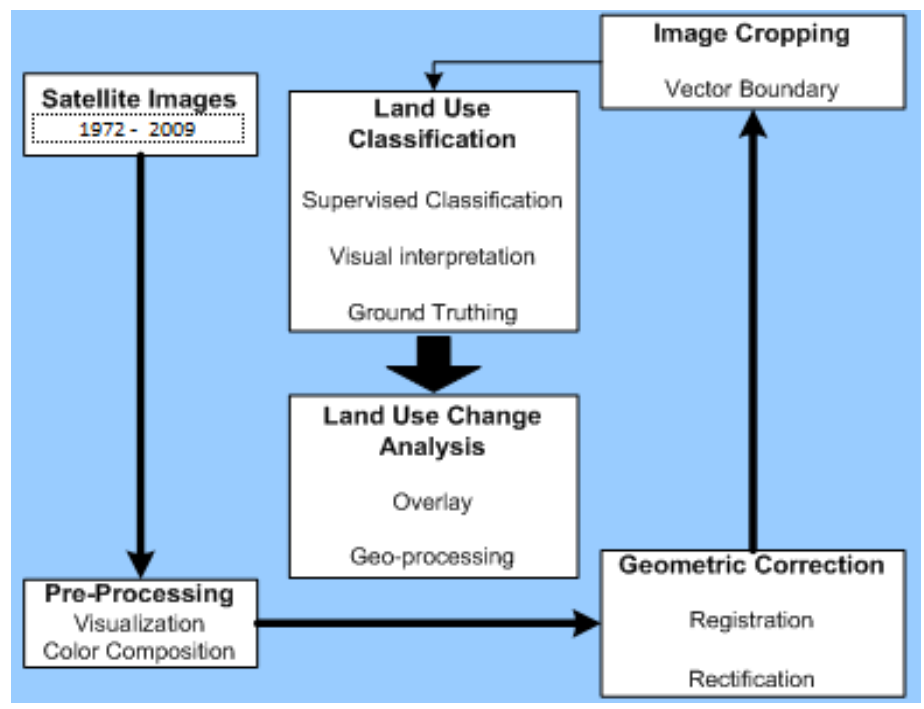

Figure 2. Image Analysis with RS and GIS

Source: Rudiarto and Doppler, 2013 with modification. 


\section{Results and Discussion}

\subsection{Urban Expansion in Semarang Metropolitan: an Examination based on Additional Built-Up Area and} Population Change

As the capital city of Central Java, Semarang has been growing rapidly. It can be indicated from Figure 3 where built-up area has been steadily increased for at least five decades. 1990s is regarded as the peak period where additional built-up areas reach more than $8000 \mathrm{Km}^{2}$. There were some remarkable development in 1990s. It was indicated that development of huge number of new urban settlement in peri-urban area of Semarang has been started in the early 1990s. There was also relocation of educational zone (Diponegoro University) from city centre to the suburb area during the period.

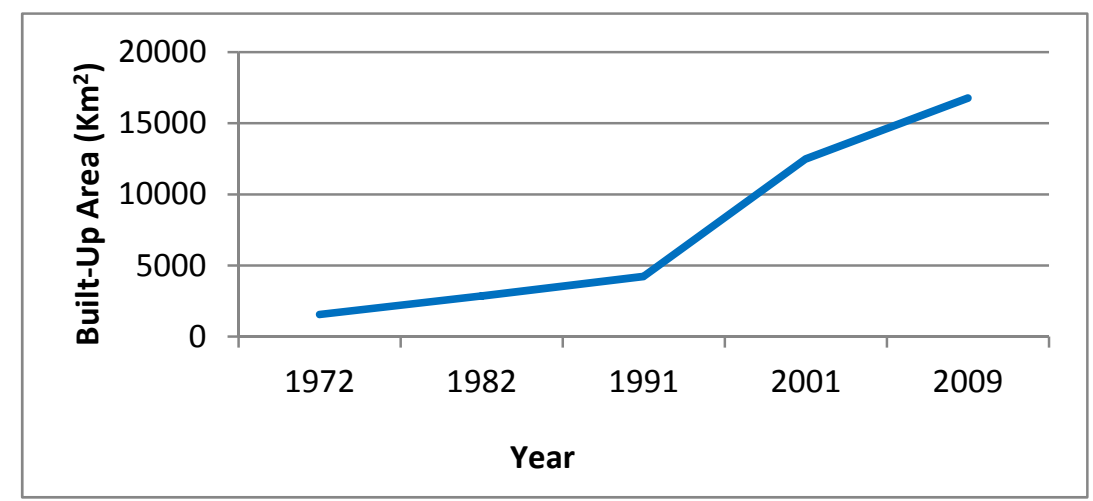

Figure 3. Additional Built-Up Area in Semarang Metropolitan, 1972 - 2009

As Torrens (2008) has revealed, urban growth that may lead to a characterization of sprawl is linked to suburbanization phenomena. Suburbanization can be indicated from the development of urban fringe area. In the phenomenon of suburbanization, the highest population density will occur in the edge region (ring). The core area is more focused on the urban activities that have higher economic value (commercial) than the settlement activity. As a result, at the stage of suburbanization, residential areas will be displaced to the suburbs. This can be either as a satellite city, a new city or other concepts that one negative result leads to the phenomenon of sprawl.

Development of new housing on large parcels of land in the peri-urban region along with increasing growth rate of in migration is regarded a common nature of sprawling. This phenomena is clearly observed in the urban growth pattern of Semarang Metropolitan. At least since 1990s, suburbanization has been characterized Semarang development. It started with the development of a satellite city $( \pm 1000 \mathrm{Ha})$ in the outskirt area of western part of Semarang. It was developed based on a concept of integrated urban development so called as Semarang New Town Development. Accordingly, Semarang Government also had been facilitated big developers to develop new settlement in the outskirt of southern, as well as eastern part until recently.

The facilitation is not only limited to middle-high class society but also to accomodate low income people in the suburbs area. Considering a high rate of land conversion as the implication of the facilitation, it is just in 2011, the local government has revised the spatial planning regulation and provide a more strict zoning regulation in the outskirt area (Planning Board of Semarang Municipality, 2011).

However, as can be seen in Figure 4, the densest area is actually concentrated only within two kilometers range from the city center. Subsequently, with the range of 3-5 km distance from city centre, built-up density is falling down quite significant. Scaterred development take place in the urban fringe of the metropolitan area. The comercial strip development where urban activities are likely to concentrate in the main road are also could be clearly observed. Indeed, accessibility should be also regarded as important variables to control sprawling phenomena. 


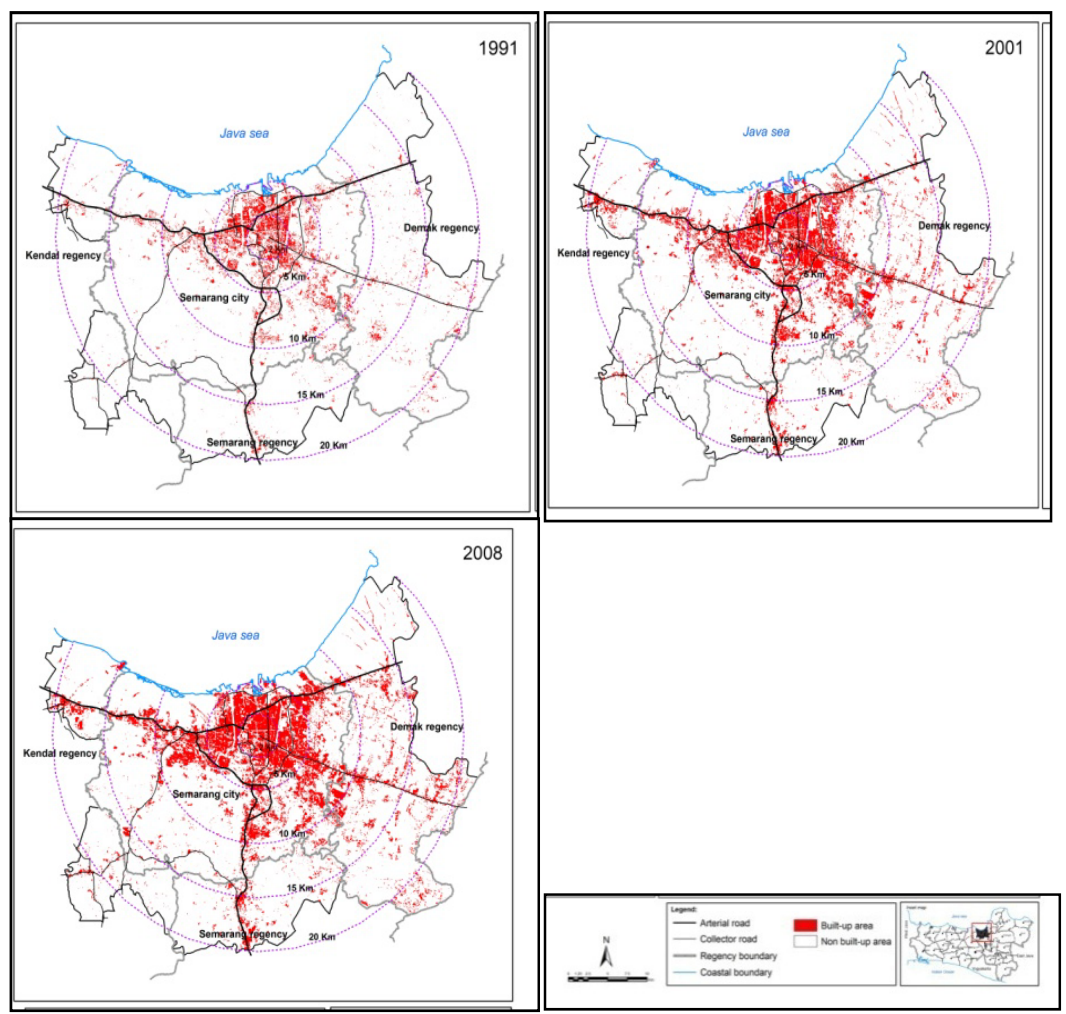

Figure 4. Built-Up Area Expansion of Semarang Metropolitan, 1991, 2001, 2008

Proportion of built-up area per one kilometer distance from city center is further described in Figure 5. The highest proportion of built-up area is within three kilometers distance from the city center. Accordingly, proportion of built-up area steadily decrease starting from the 4th kilometer and beyond.

Addition in built area have significantly related to population changes. In the very common situation, population pressure will lead to significant additional built-up area. By combining data of built-up area and population change, it can be indicated how urban activity are developed and allocated. There is an interesting finding from the comparison of Figure 5 and 6 . While additional built-up area is likely to decrease, Semarang inhabitants is concentrated in the range of 3-5 km. However, population growth in the 3rd kilometer distance is likely to decrease while population growth in the 4 th and 5 th kilometer distance are increase quiet significant. Indeed, the two graphs (Fig. 5 and Fig. 6) are clearly indicated that Semarang Metropolitan has been experiencing suburbanization.

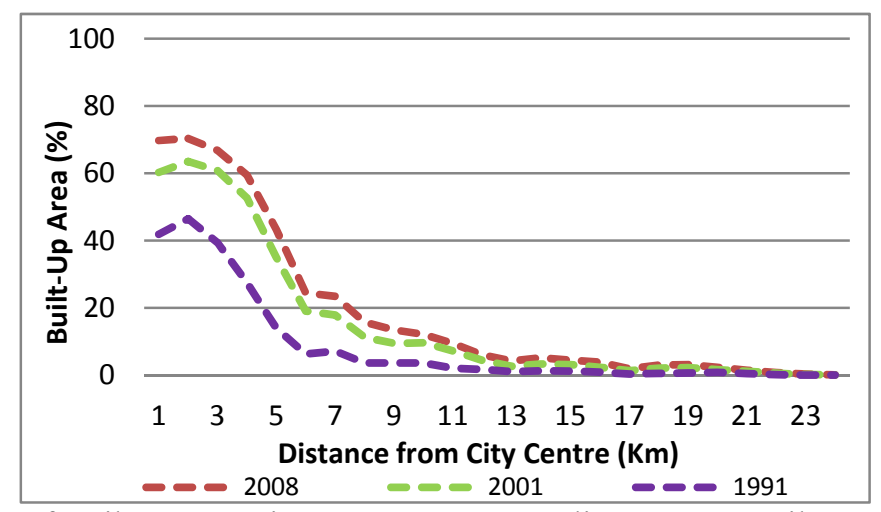

Figure 5. Proportion of Built-Up Area in Semarang Metropolitan per One Kilometer 1991, 2001, 2008 


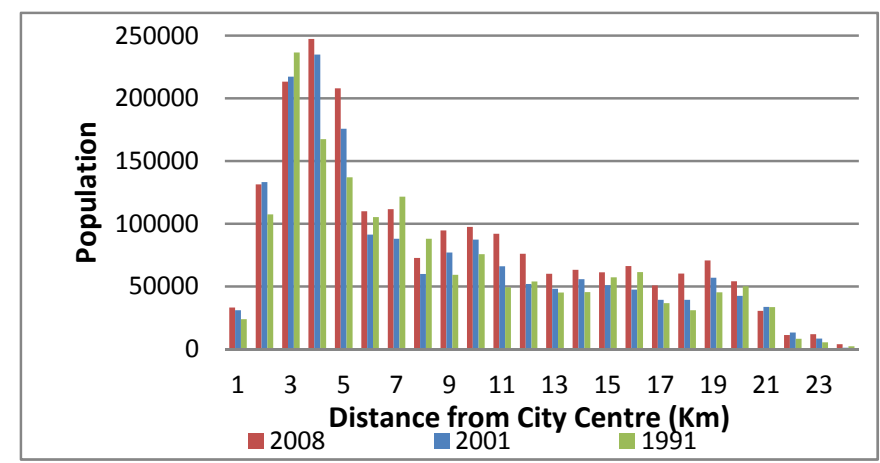

Figure 6. Number of Population per One Kilometer 1991, 2001, and 2008

\subsection{Urban Expansion in Semarang Metropolitan: An Examination based on Population Density}

To further comprehend the urban expansion of Semarang Metropolitan, the population gross and net density (average persons/ha) was plotted with distance from the city centre applied as the main function (see Fig. 7). As illustrated in the Figure 7, by focusing on the population net density, Semarang Metropolitan has had experienced of decreasing population in the center in 2008, particularly in the range of 3-5 km. In the range of 7-13 km from the city center, Semarang Metropolitan shows a steady increasing population density following with a significant decrease from distance $17-20 \mathrm{~km}$. Concerning on the net density pattern, it is very likely that suburbanization has been taken place in the case of Semarang Metropolitan. A steady increasing population density in the range of 7-17 km may provide indication that there is a tendency of huge number of settlement area in this zone while the urban center is functioned more as commercial zone.

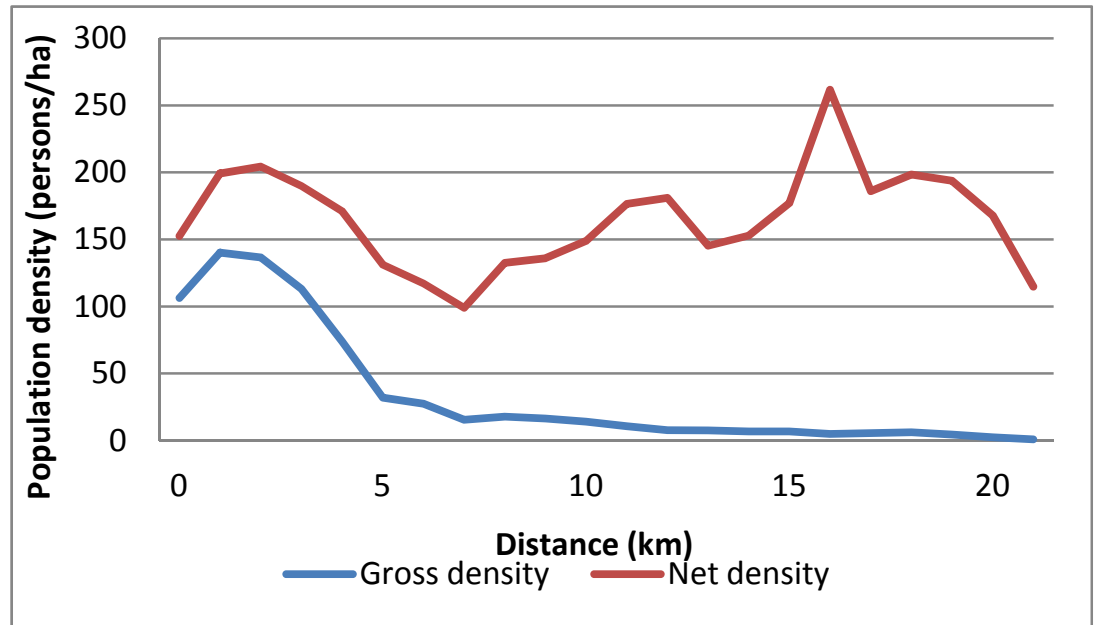

Figure 7. Population Density as a Function of Distance from City Center in Semarang Metropolitas, 2008

Pattern of the population net density is completely different with the pattern of population gross density. While the net density pattern is likely to be very unsteady, the population gross density shows a more stable pattern. What has had happened in Semarang Metropolitan is quiet similar with those has had been experienced in the three mega cities in South East Asia, i.e. Jakarta, Bangkok, Metro Manila in 1970-1998 as illustrated in Figure 8 (Murakami et al, 2005). However, the density pattern in the Semarang Metropolitan take place in a lower rate of density and in a closer distance indicating that urban expansion of Jakarta, Bangkok and Manila has had been taken place in a greater area.

The case of Semarang Metropolitan is very similar with Bangkok and Metro Manila in 1990s. Range of 3-5 km were regard as the critical distance to indicate the decreasing number of population density. While for the case of Jakarta during the same period, the critical distance was five $\mathrm{km}$. By comparing Figure 7 and Figure 8, regardless the different time of the data that have been applied, it seems like Semarang Metropolitan has been experiencing a similar urban expansion pattern in comparison to Jakarta, Bangkok and Metro Manila. 


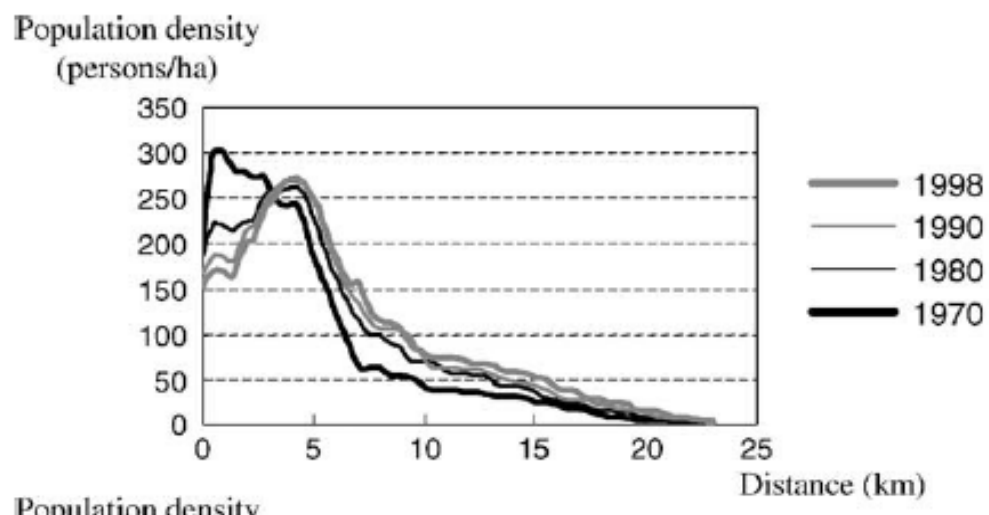

Population density (persons/ha)

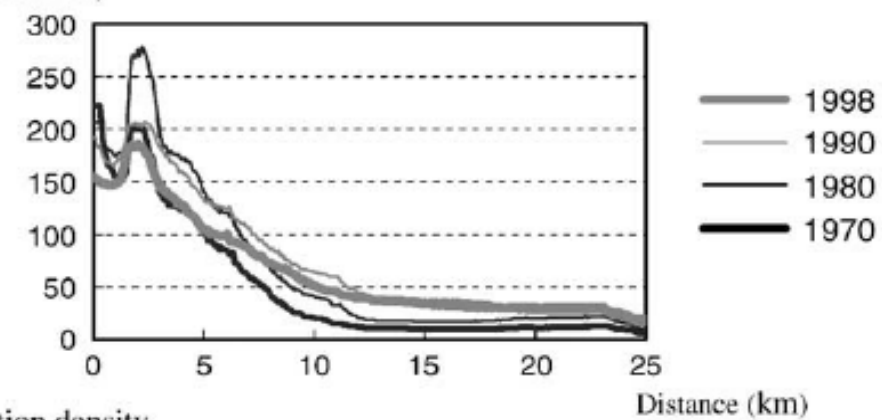

Population density (persons/ha)

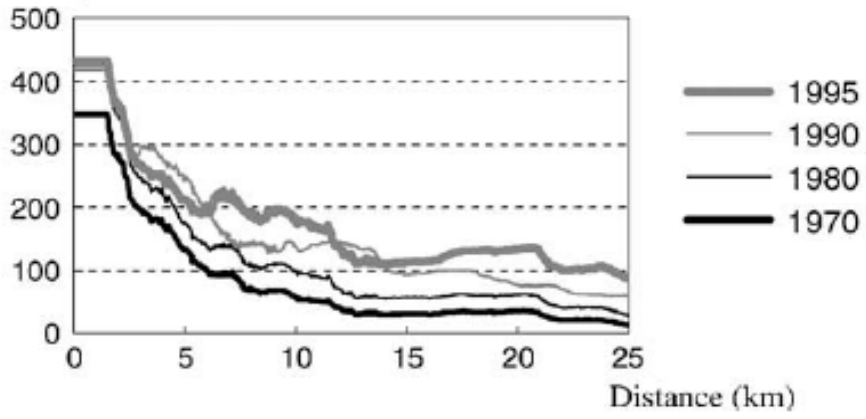

\section{Jakarta}

\section{Bangkok}

\section{Metro Manila}

Figure 8. Population Density as a Function of Distance from City Center in Jakarta, Bangkok, and Manila Source: Murakami et al, 2005.

\section{Conclusion}

The analyses result show that suburbanization has been taken place in Semarang Metropolitan. The suburbanization phenomenon closely related to sprawling so called as suburban sprawl. Referring to Murakami et al (2005) study, the emerging pattern is very common in Asian cities as it is very much similar with the pattern in view selected cities in the neighboring countries. Eventhough there is a lot of debate to clearly define and measure the dynamics of suburban sprawl, indeed, it should be anticipated to have a more efficient public services provision and higher quality of life.

\section{Acknowledgments}

This research is funded by the Engineering Faculty of Diponegoro University under its featured research scheme.

\section{References}

Breheny, M. (2005). “Centrist, Decentrist and Compromisers: Views on the Future of Urban Form”. In M. Jenks, E. Burton, \& K. Williams (Eds.). UK: Taylor \& Francis e-Library.

CBS (Central Bureau of Statistics). (2001). Jawa Tengah dalam angka tahun 2001 / Central Java in figures year 2001. Semarang: Author. 
CBS (Central Bureau of Statistics). (2010). Jawa Tengah dalam angka tahun 2001 / Central Java in figures year 2010. Semarang: Author.

Champion, T., \& Hugo, G. (Eds.). (2004). New forms of urbanization. Cornwall: International Union for the Scientific Study of Population (IUSSP).

Cohen, B. (2003). Urban growth in developing countries: current trends, future projections, and key challenges for sustainability. Technology and Society, 28, 63-80. http://dx.doi.org/10.1016/j.techsoc.2005.10.005

Douglass, M. (2000). Mega-urban regions and world city formation: globalization, the economic crisis and urban policy issues in pacific asia. Urban Studies, 37(12), 2315-2335. http://dx.doi.org/10.1080/00420980020002823

Firman, T. (2004). Demographics and spatial patterns of Indonesia's recent urbanization. Population, Space and Place, 10, 421-434. http://dx.doi.org/10.1002/psp.339

Galster, G. et al. (2001). Wrestling sprawl to the ground: defining and measuring elusive concept. Housing Policy Debate, 12, 681-717.

Handayani, W. (2013). Rural-urban transition in Central Java: population and economic structural changes based on cluster analysis. $L A N D, 2(1)$. http://dx.doi.org/10.3390/land2030419

Iaquinta, D. L., \& Drescher, A. W. (2000). Defining the peri-urban: rural-urban linkages and institutional connections. Land Reform, 2.

Jabareen, Y. F. (2006). Sustainable urbvan forms: Their typologies, models, and concepts. Journal of Planning Education and Research, 26, 38-52. http://dx.doi.org/10.1177/0739456X05285119

Jenks, M., Burton, E., \& Williams, K. (Eds). (2005). The compact city: a sustainable urban form? UK: Taylor \& Francis e-Library.

Jones, G. W. (2002). Southeast Asian urbanization and the growth of mega-urban regions. Journal of Population Research, 19(2).

Murakami, et al. (2005). Trends in urbanization and patterns of land use in the Asian mega cities Jakarta, Bangkok, and Metro Manila. Landscape and Urban Planning, 70, 251-259. http://dx.doi.org/10.1016/j.landurbplan.2003.10.021

Phillips, D., et al. (1999). Literature review on peri-urban natural resource conceptualisation and management approaches. Final Technical Report, DFID Natural Resource System Programme (NRSP), Project R6949, University of Nottingham and University of Liverpool.

Planning Board of Semarang Municipality. (2011). Spatial Development Plan 2011-2031. Semarang: Author.

Pratiwo. (2004). "The city planning of semarang 1900-1970”. Surabaya: Airlangga University and Nederland Instituut voor Oorlogsdocumentatie.

Rudiarto, I., \& Doppler, W. (2013) "Impact of land use change in accelerating soil erosion in Indonesian upland area: a case of Dieng Plateau, Central Java-Indonesia." International Journal of AgriScience, 3(7), 558-576.

Tambunan, T. (2003). Perkembangan sektor pertanian di Indonesia: Beberapa isu penting / Agricultural sector development in Indonesia: Some important issues. Jakarta: Ghalia Indonesia.

Torrens, P. M. (2008). A toolkit for measuring sprawl. Appl. Spatial Analysis, 1, 5-36.

Tsai, Y. (2005). Quantifying urban form: Compactness versus 'sprawl'. Urban Studies, 42(141). http://dx.doi.org/10.1080/0042098042000309748

United Nations (UN). (2004). World Urbanization Prospects (the 2003 revisions). New York: Author.

\section{Copyrights}

Copyright for this article is retained by the author(s), with first publication rights granted to the journal.

This is an open-access article distributed under the terms and conditions of the Creative Commons Attribution license (http://creativecommons.org/licenses/by/3.0/). 